\title{
The change of gait analysis on applying metatarsal-bar used 3D motion analysis
}

\author{
Se won Yoon ${ }^{1 *}$, Jeong woo Lee ${ }^{1}$, Soo ji Park ${ }^{2}$, Woong sik Park ${ }^{3}$, Moon jeong Kim ${ }^{4}$ \\ From 4th Congress of the International Foot and Ankle Biomechanics (i-FAB) Community \\ Busan, Korea. 8-11 April 2014
}

\begin{abstract}
Introduction
Enough dorsiflexion angle of the first metatarsophalangeal joint is needed to ensure thrust and stability [1], and if the range of motion of the first metatarsophalangeal joint decreases, normal foot function during gait is under severe restriction [2]. Wearing shoes with high heels during gait makes weight leaning forward and wearing them for long may cause deformation of hallux valgus $[3,4]$. General therapeutic concepts of foot diseases focus on reducing or eliminating plantar tissue stress. Recently, studies on treatment to solve these problems have been conducted, but there have been a few studies on orthotic devices such as metatarsal pad, dome and wedge [5].

Therefore, this study applied bar metatars ophalangeal area of normal persons and examined if any change occurs of spatio-temporal indices and kinematic parameters by using 3D motion analysis system.
\end{abstract}

\section{Method}

This study selected 40 female university students in their twenties and conducted the experiment with them before and after applying metatarsal bar. Spatio-temporal indices including stance phase, swing phase, double phase, cadence, stride time, stance phase time, swing phase time, double stance phase time, step length, stride length, velocity, stride velocity, and swing phase velocity were measured through 3D motion analysis system and kinematic parameters such as pelvic tilt angle, hip joint flexionextension angle, knee joint flexion-extension angle, foot progression angle, and ankle joint flexion-extension angle were also measured through 3D motion analysis system.

After attaching metatarsal bar to the subjects on bare foot, they had enough practice in laboratory to make

\footnotetext{
* Correspondence: ptyoon2000@mail.kwu.ac.kr

'Department of physical therapy, Kwangju women's university, Kwangju, 506-713, Korea

Full list of author information is available at the end of the article
}

them accustomed to gait. Before experiment, calibration was conducted, gait space was measured and then subsequent experiment was carried out.

Marker was at attached to joint and photographing was made at the condition that reflective materials except marker were eliminated within the camera view. Marker was at attached to sacrum (1), anterior superior iliac spine (left, right), greater trochanter (left, right), femur $1 / 2$ location (left, right), lateral epicondyle of femur (left, right), fibular head (left, right), tibia $1 / 2$ location (left, right), lateral malleolus (left, right), 5th metatarsal head (left, right), and heel (left, right). Marker should be attached to be seen in a straight line from side to measure the accurate angle and the subjects were made to stand in the middle of gait path and look at the front.

The subjects are made to stand at the starting point of the path to measure the dynamic gait and their gaits were measured after comfortable walking by measurer's instruction. The subjects wore shorts to prevent the sway of marker during gait and preferred walking velocity was used as gait velocity.

\section{Result}

As a result of analyzing gait, knee joint angle showed significant difference and remaining variables showed no significant difference.

\section{Conclusion}

This study was showed significantly decreased that change of knee joint angle on applying metatarsal-bar. It was the same change when wearing high heel appears that general knee joint decreased. We think that applying metatarsalbar wasn't influence on change of knee joint angle. Also gait parameter on applying metatarsal-bar showed no significantly difference, we suggest that metatarsal-bar is helpful to foot diseases patients. 


\section{Authors' details}

'Department of physical therapy, Kwangju women's university, Kwangju, 506-713, Korea. ${ }^{2}$ Department of physical therapy, Graduate school, Kwangju women's university, Kwangju, 506-713, Korea. ${ }^{3}$ Department of occupational therapy, Kwangju women's university, Kwangju, 506-713, Korea. ${ }^{4}$ Department of physical therapy, Shinhwa rehabilitation clinic, Busan, Korea.

Published: 8 April 2014

\section{References}

1. Hetherington $V$, Johnson R, Albritton J: Necessary dorsiflextion of the first metatarsophalangeal joint during gait. The journal of foot surgery 1990 29(3):218.

2. Hopson M, McPoil T, Cornwall M: Motion of the first metatarsophalangeal joint. Reliability and validity of four measurement techniques. Journal of the american podiatric medical association 1995, 85(4):198-204.

3. Voloshin A, Wosk J: An in vivo study of low back pain and shock absorption in the human locomotor system. Journal of biomechanics 1982, 15(1):21-27.

4. Nyska $M, M c C a b e ~ C$, Linge $K$, et al: Plantar foot pressures during treadmill walking with high-heel and low-heel shoes. Foot \& ankle international 1996, 17(11):662-666.

5. Yoon MC: The effect of metatarsal pad on peak plantar pressures of the forefoot during walking. Kyonggi university 2007, Master's degree.

doi:10.1186/1757-1146-7-S1-A99

Cite this article as: won Yoon et al:: The change of gait analysis on applying metatarsal-bar used 3D motion analysis. Journal of Foot and Ankle Research 2014 7(Suppl 1):A99.

\section{Submit your next manuscript to BioMed Central} and take full advantage of:

- Convenient online submission

- Thorough peer review

- No space constraints or color figure charges

- Immediate publication on acceptance

- Inclusion in PubMed, CAS, Scopus and Google Scholar

- Research which is freely available for redistribution

Submit your manuscript at www.biomedcentral.com/submit
C Biomed Central 